\title{
Determinants of Innovation Capability: An Exploratory Study of Inclusive Leadership and Work Engagement
}

DOI: 10.12776/QIP.V25I2.1596

\author{
Nenad Vladić, Damjan Maletič, Matjaž Maletič \\ Received: 2021-07-19 Accepted: 2021-07-28 Published: 2021-07-31
}

\begin{abstract}
Purpose: The purpose of this paper is to explore how innovation capability can be enhanced by inclusive leadership. In particular, the focus is on identifying the key drivers of work engagement and the role of leadership in boosting the innovation capability.
\end{abstract}

Methodology/Approach: This research has a qualitative exploratory nature. The exploratory fieldwork is based on an in-depth interview with the CEO, field observations and on the analysis of relevant corporate sources.

Findings: The research provides further confirmation of the link between inclusive leadership, work engagement and innovation capability. Specifically, authentic communication and leadership traits such as trust, courage, humility, empathy and gratitude are considered to be among the most important enablers of an inclusive environment that leads to business success.

Research Limitation/Implication: This study contributes to a better understanding of how companies could enhance innovation capabilities by leveraging the power of inclusion. The subjective business evidence coming from only one company constitute the main limitations of the present study.

Originality/Value of paper: This paper contributed to leadership and innovation literature. The results of this work provide a thorough understanding of the mechanisms for improving work engagement and, consequently, innovation capability. By grounding our research in both theory and empirical evidence, we provide valuable insight for both academia and practice.

Category: Research paper

Keywords: innovation capability; inclusive leadership; work engagement; case study 


\section{INTRODUCTION}

With the global acceptance of health measures against the spread of the coronavirus pandemic, two important factors have occurred that will have a significant impact on the business operations of companies in the future. The first is the global economic crisis, which has exposed all the weaknesses of existing business models, because the economy was not prepared for such challenges, there have been mass layoffs and the collapse of many companies. The second is a new geopolitical reality that will dictate further global economic relations and the way companies operate within them.

Indeed, the main driver of change in the next decade will be the business ecosystem (Lyman, Ref and Wright, 2018). This is an economic community supported by a foundation of shared organizations and individuals, i.e., organisms of business whose goal is to create a healthy, loose community of companies and organizations that can continuously evolve to survive rapid and disruptive market changes (Moore, 1993). In a world of increasingly specialized organizations, a single organization usually lacks the internal resources to develop and implement innovations. Therefore, organizations must rely on input from a variety of internal and external stakeholders to create value across the ecosystem (Talmar et al., 2020).

On the other hand, new digital technologies such as nanoelectronics, quantum computing, high-performance telecommunications networks and artificial intelligence pose an additional challenge. These herald the 5th Industrial Revolution and in themselves require the introduction of different and new ways of running modern organizations. In this context, the new approach envisages collaboration between people and technology, with the aim of mass customization of products and services to the user. This means that the employee will leave the manufacturing process to the machines and technologies, while he himself will be much more involved in the planning and design process. This increases the individual's field of activity, which consequently increases the employee's scope of work and responsibility (Doyle-Kent and Kopacek, 2020). Moreover, from the findings of the studies conducted earlier, it could be ascertained that leadership plays an important role in meeting the challenges of modern industrialization (Turisova et al., 2020).

Overall, the focus is on innovation, which is directly dependent on leadership and work engagement. In this regard, there are two challenges. The first relates to innovation, which is reflected in different perceptions of innovation by owners and managers on the one hand and employees on the other. Namely, owners and managers prioritize an innovative culture as something they want to spend the most time and resources on. This is not surprising as they see innovation as an opportunity to develop and create value. On the other hand, employees increasingly associate innovation with "danger" rather than "opportunity" (Zhexembayeva, 2020). They see them as an increased workload without results or even a threat of dismissal of employees if the innovation is realized. 
The second challenge relates to employee work engagement, which remains low despite large financial investments. It is a modest $21 \%$ in the EU and $15 \%$ in Slovenia (Schaufeli, 2018). The main problem is that most initiatives to increase work engagement focus on short-term employee enthusiasm in terms of rewarding work performance. To improve results, a reward or benefit is given, but over time the effect wears off and results decline. To improve results, management introduces new benefits that fade and lose effectiveness after a period of time (Morgan, 2017).

While previous research has focused primarily on the relationship between innovation and transformational leadership, this research will examine the relationship between innovation and inclusive leadership. Recall that transformational leadership focuses on the leader's own quality to gain the respect of followers, which can increase their optimism in achieving goals (Eagly, Johannesen-Schmidt and Van Engen, 2003). On the other hand, inclusive leadership is an extension of t.i. relational leadership and understands the call for employees to contribute their own skills and respect for individual talents (Avery et al., 2008).

In addition, both the global economic crisis and digitalization bring to the fore the central question: how can employees be managed in such a way that individual systems deliver the best results and survive possible economic or societal shocks in the future without major shocks? Therefore, the aim of the research is to examine the role of the leader in nurturing employees and achieving innovativeness. In this regard, the aim of the research is to identify elements of inclusive leadership that have a significant impact on employee and organizational work engagement and innovativeness. The solutions obtained will help organizations that want to implement an inclusive leadership style to increase engagement and innovativeness.

This study is a contribution to the literature that provides insight into the study of the relationship between inclusive leadership and innovation and employee engagement. At the same time, it enables all interested companies and leaders in the local environment to calibrate their leadership methods in order to achieve greater innovation capability and thus efficiency in the global marketplace.

The paper is organized as follows. Section 2 presents the theoretical foundations and examples of each of the three conceptual mechanisms (i.e., innovation capability, inclusive leadership, and work engagement). Sections 3 and 4 successively present our methodological approach and the derived results. Sections 5 and 6 discuss and conclude. 


\section{LITERATURE REVIEW}

\subsection{Innovation Capability}

Innovation capability is defined as the ability to (1) develop new products that meet market needs; (2) use appropriate process technologies to produce these new products; (3) develop and adapt new products and processing technologies to meet future needs; (4) and respond to serendipitous technological activities and unexpected opportunities created by competitors (Adler and Shenhar, 1990).

In this sense, innovation capability is defined as "an important factor that enables innovative organizational culture, the characteristics of internal facilitating activities and the capabilities to understand and respond appropriately to the external environment" (Akman and Yilmaz, 2008). It should be emphasized that innovation capability is fundamentally a potential, that is, something that all companies have, regardless of whether they innovate occasionally or constantly (Som, Kirner and Jäger, 2015). Accordingly, innovation capability represents the potential for developing innovations.

It is therefore not surprising that innovation capability is referred to as a key means of achieving competitive advantage and sustainable success of an organization (Liao et al., 2017). Organizational innovation has various aspects depending on how it is viewed. It can be viewed in terms of organizational structure in terms of the degree of centralization and formalization that affects the flow of innovative ideas and how a company handles them from inception to implementation, how it assigns tasks to members, and how it makes decisions. From a process perspective as an approach to developing and implementing new ideas in relation to organizational processes as its learning capability. Organizational innovation can also be considered in terms of organizational change as the practices it uses to respond to market changes and overcome resistance to change (Prasad and Junni, 2016).

In this context, innovation capabilities have been classified by experts into different categories. Lawson and Samson (2001) in their study state that innovation capability consists of seven different elements, namely: vision, core competencies, organizational intelligence, creativity, idea management, organizational structures, culture and climate, and technology management. Terziovski (2007) suggests only two categories: Collaboration and Knowledge Transfer. Björkdahl and Börjesson (2012) mention that innovation capability is expressed as follows: Innovation strategy, prioritization, culture, idea management, external environment and linkages, implementation, decision making systems and rules, organizational context and learning systems and decision making rules, organizational context and learning.

The most common dimensions in which innovation capability occurs are: Knowledge management, organizational culture, organizational learning, 
leadership, collaboration, creativity, idea management, and innovation strategy (Iddris, 2016).

Scholars have found that organizations need to address various aspects of innovation capability to fully improve innovation (Agarwal and Selen, 2009; Anderson, Potočnik and Zhou, 2014; Le and Lei, 2019). While most studies focus on examining innovation capability in general, this research will focus on examining individual and organizational innovation capability.

\subsection{The Impact of Inclusive Leadership on Innovation Capability}

Numerous scientific studies have shown that leadership has a positive influence on the ability of employees and the company to innovate. In this regard, the role of leadership (Aragón-Correa, García-Morales and Cordón-Pozo, 2007) is: (1) to motivate the company rather than control it; (2) to coordinate activities at lower, middle and top levels; (3) to encourage employees to try new ideas without fear of failure or consequences; (4) to encourage employee participation in innovation activities; (5) to create structures to support innovation activities.

Leaders need to focus on motivating and encouraging people to be more successful and aligning all employees with a vision and purpose (McMillan, 2010). Acceptable visions have three purposes: first, the vision clearly states the overall direction of change. Second, it motivates employees to take a step in the right direction, even if the steps are not easy and may even be painful. Third, the vision helps to coordinate the actions of a large number of people extremely quickly and efficiently (Kovač, Mühlbacher and Kodydek, 2012). Leaders inspire their followers, make them aware of the importance of the organizational mission and goals so that they can think creatively and act above expectations. Leaders recognize the contributions of followers and constantly encourage them to seek new ideas inside and outside the organization. At the same time, they promote organizational learning, which is considered one of the most important precursors of organizational innovation (Villaluz and Hechanova, 2018).

The role of managers is to set the goals of the innovation strategy and inform their employees about them, while justifying why they must be achieved. Leaders provide guidance, advise on organizational priorities, and create a supportive environment for implementing innovation initiatives. Leaders help individuals trust themselves, participate in the decision-making process, and set high goals for themselves. They constantly communicate sincerely with their employees and deepen their relationships, which increases job satisfaction, improves work engagement, and resolves conflict. Under such circumstances, followers are willing to accept challenging tasks if they know that their leaders will support them and provide the necessary help (Szczepańska-Woszczyna, 2015).

To this end, various types of leadership are employed, of which transformational leadership has been the most common and well-studied for some time, while recently there has been an increase in research in the area of inclusive leadership. Nembhard and Edmondson (2006) were the first to point out the introduction of 
inclusive leadership in management in terms of how managers communicate and behave to encourage their subordinates to work and create benefits. Involved leadership is described as a type of relational leadership where the manager is always available to their subordinates (Choi, Tran and Kang, 2017). The relationship of an inclusive leader is based on empathy, respect for all employees, their personalities and specific talents, based on an environment where each individual can express their ideas and suggestions without fear. Taking into account the diversity of the entities involved, the inclusive leader helps to build shared knowledge and create an organizational climate with a sense of belonging and flexibility to maximize individual and team innovation and consequently achieve competitive results. Based on the above arguments, the following research question is proposed:

RQ1.: How could managers increase the innovation capability of employees and the organization by encouraging employee engagement?

\subsection{The Impact of Work Engagement on Innovation Capability}

People demonstrate engagement when they physically engage in tasks, either alone or with others; they are cognitively alert, focused, and attentive; they are emotionally connected to their work and to others in the service of their work (Kahn, 1990). While work engagement is usually defined as "a positive, fulfilling, work-related state of mind characterized by vigor, dedication, and absorption" (Schaufeli et al., 2002). In this sense, engaged employees are active agents who believe in themselves and generate their own positive feedback. At the same time, they have values that are consistent with the organization, sometimes feel tired but satisfied, and are engaged outside of work.

Later, the concept of work engagement evolved from the study of the relationship between employees and their work to its association with human resources, work behavior, and psychology. In this regard, engagement consists of behavioral, emotional, and cognitive components whose common goal is realization in the form of energy, rational and emotional commitment, deep connection, positive attitude, and psychological presence (Rich, LePine and Crawford, 2010).

In realizing the above ideas or standards of work engagement, conditions and opportunities are created to think outside the box, discover individual potential in employees and cooperate with each other to innovate at the individual and organizational level. Thus, it is no longer just a question of how to enable employees to be engaged, but also how to motivate them to innovate (De Spiegelaere et al., 2015). Leaders of modern organizations are increasingly aware of the importance of organizational cultures characterized by adaptability, flexibility, and responsiveness (Denning, 2013). As a result, researchers are beginning to look beyond formal leadership styles, which have been predominantly associated with transformational leadership, and are instead exploring a range of more inclusive leadership styles (Caulfield and Senger, 2017). Therefore, in the current environment, it seems useful to try to understand 
how engaged employees are, as collaboration is crucial in the field of innovation. (Alblooshi, Shamsuzzaman and Haridy, 2020). Following this line of reasoning, this study proposes the following research question:

RQ2.: What factors significantly influence work engagement and innovation capability?

\section{METHODOLOGY}

\subsection{Empirical Method and Field Work}

To answer the question raised, a qualitative exploratory study, a single case study, was designed (Yin, 2018). It was decided to use a qualitative study methodology as it is suitable for analyzing the complex process of determinants of innovativeness and allows for deeper perception and understanding of the subject under study (Eisenhardt, 1989; Yin, 2018). To ensure that the data collected reflect real experiences and not a priori judgments about the studied topic, only the most innovative firms (i.e., based on the list of companies outlined in Slovenian National Innovation Awards) were included in the sampling frame from which the present case was selected. The case company was purposefully selected to provide an appropriate research setting. We also restricted our sample frame according to the following criteria: Innovation award (C1 - national and international awards were considered); type of industry (C2 - manufacturing); age of the company (C3 - more than 10 years); research and development (R\&D) activities (C4 - internal R\&D activities); charismatic leadership (C5 - publicly available evidence). In view of the the above, Pipistrel d.o.o. was selected as one of the most innovative companies in European Union and companies that fit our selection criteria.

The fieldwork and investigation was developed over a period from summer 2014 to spring 2017 as part of a case study. The subject of the research is the highly innovative company Pipistrel d.o.o., which is a leader in its field and achieves excellent results in the global market. Anderson, Potočnik and Zhou (2014) state that the topic area of the relationship between strategic leadership and innovation is the most important, but so far rather neglected in empirical studies. Accordingly, the research is based on a 120-minute semi-structured interview conducted with the founder Ivo Boscarol for the needs of the book From Talent to Success (Vladić, 2017). In the research, we will additionally rely on the book written by the author of Ivo Boscarol, NASA Blog (Boscarol, 2011), which was written during the NASA Green Flight Challenge won by Pipistrel with the Taurus G4, the world's first four-seat electric aircraft. In addition, we will also use other literature and documentation available on the World Wide Web. Therefore, following Barratt, Choi and Li (2011), semi-structured interviews, archival sources (e.g., documents, websites, interviews, articles, books, etc.), and filed observations were used for the purpose of data collection (Table 1). 
Table 1 - Summary of a Data Collection Approach

\begin{tabular}{|c|c|c|c|c|}
\hline Company & $\begin{array}{c}\text { Period of data } \\
\text { collection and } \\
\text { investigation }\end{array}$ & $\begin{array}{c}\text { Semi-structured } \\
\text { in-depth interviews }\end{array}$ & Archival sources & Observation \\
\hline $\begin{array}{c}\text { Pipistrel d.o.o. } \\
\text { Aviation \& } \\
\text { aerospace company } \\
\text { based in Slovenia } \\
\text { Year of } \\
\text { establishment: } \\
1989\end{array}$ & $2014-2017$ & $\begin{array}{c}\text { In-depth interview } \\
\text { with the founder } \\
\text { and Chief } \\
\text { Executive Officer } \\
\text { (CEO) }\end{array}$ & $\begin{array}{c}\text { Internal company } \\
\text { documents and } \\
\text { presentations } \\
\text { provided by senior } \\
\text { management } \\
\text { Official reports } \\
\text { Official websites }\end{array}$ & Field research \\
\hline
\end{tabular}

\subsection{Research Environment}

Pipistrel d.o.o. is a world leader in the ultralight aircraft industry and in the field of electric aircraft development. It continuously receives many prestigious international recognitions and awards, which speaks for its innovation, sales performance and wide recognition. To get an insight into the uniqueness of the company, let's take a look at some key milestones. In 2010, Pipistrel won the European Business Award for the most innovative company in Europe in a competition of 15,000 companies. In 2015, they won the tender in a competition of 11 bidders and signed a contract with Indian Army for the delivery of approximately 200 Virus SW aircraft for a total value of $€ 20$ million. In 2018, an electric taxi with vertical take-off and landing was unveiled at the Uber conference in Los Angeles. Pipistrel is currently a world leader in the development of electric propulsion and a true pioneer of usable carbon-free aviation for both commercial and passenger transport.

\section{QUALITATIVE RESEARCH RESULTS}

Right at the beginning of the conversation, Ivo Boscarol emphasizes the importance of the individual value system, consistently setting success as a paradigm that has positive qualities and noble intentions:

"There is only a fine line between success and greed. Success must be our main goal in life, we must take pride in it and trust ourselves because of it. Aiming high is important. Trust is one of the values that is very important in business and in life. If you have confidence in your people and the courage to trust yourself, you can sell sand in the Sahara." (CEO, Pipistrel)

Personal values occupy a central place in the system of inclusive leadership, as they are the basis of all actions in advance and collaboration with stakeholders, partners and employees. The leader's personal values create and shape the organizational climate, interpersonal relationships, work engagement, and the individual's ability to innovate. To emphasize the importance of personal values 
in business and life, and a clear shift away from the type of success that has negative consequences, he continues:

"It is greed that produces a life beyond circumstances and means, to bury values, that is the problem. In fact, we blur the need between what is wanted and what is needed. Capital has re-educated us so much today that we buy 65 percent of the things we don't need. Those 65 percent of things are what make us unhappy [...]. Money is so important to me, that I have a regular salary and that I know we can work normally. And that I have as much as I need for double jeans and gas; I don't need more." (CEO, Pipistrel)

In consequence, this means that the inclusive leader is willing to invest two of his or her most important resources, energy and time, in the given development of the inclusive business environment and the related organizational climate. In doing so, the leader clearly demonstrates to his or her employees that he or she is not merely delegating work, but is directly involved in creating a healthy climate and seeks to reach out to each employee. In turn, employees recognize that this is an honest and committed person who will consequently choose to believe, follow, and internalize the vision of such a leader. This is supported by the event of the 10th day of NASA Green Flight Challenge in the US, which the founder and owner of Pipistrel writes about:

"Yesterday, the usually frugal Gregor (note: Dr. Gregor Veble, research director at Pipistrel) came up to me and said, 'You know, I have to thank you for making it possible for me to experience what I am experiencing now. I never thought I could be a part of a story like this. Thank you'. [...]. That is the biggest thank you an employer can get from their employee." (Boscarol, 2011, p.91)

On the other hand, a healthy organizational climate centered on employees means the expression of views, ideas and criticisms in relation to all activities that are part of the business system. An interesting note in terms of confirming this relates to the event after which Ivo Boscarol made a proposal to NASA's Chief Technical Officer to give universities, institutes and industry 3 years to improve competition and offer them $\$ 5$ million:

"The idea belongs to Tine (note: Tine Tomažič, development engineer) anyway. When we revealed it to our team, Jure (note: Dr. Jure Tomažič, senior electrical engineer) got angry: 'It's easy for Tine, he fades something out, and then we all have to work like crazy because he has a long tongue!' This is very true, but without hard work there are no results, no satisfaction, no success. We know that already. Everyone. But because of ideas and hard work, we are all living our craziest dreams here now!" (Boscarol, 2011, p.91)

The inclusive leader wants to create a climate in which every employee can express his own opinion. He is aware that the work environment is composed of people whose characters, prior experiences, and worldviews differ from one another. Therefore, the leader's goal is to involve employees in such a way that 
they can express their own personalities and at the same time feel like an indispensable part of the team, as Pipistrel's CEO points out:

"There are many people who think differently, you just must not restrict them. You can't put obstacles in their way. If I told my developers what to do every day, we wouldn't get anywhere. The fact is that young people in particular have to have their own challenges, have to think for themselves. You give them a certain financial framework, you give them the experience you have, the strategy, the vision we're going to pursue, and you might give them the concept. Lately, my aircraft design is limited to a concept, I just say, 'This and that will sell in twenty years, and you do it. ", (CEO, Pipistrel)

Indeed, such teams grow professionally and personally, have high levels of work engagement, build their capability to innovate, and achieve excellent business results. The key components of the leader involved are empathy and gratitude, with which the leader shows employees that they are valuable and important in his eyes, while at the same time he spontaneously encourages them:

"A special thanks to all of you at Pipistrel who responsibly and conscientiously do your jobs while we spend the money you have created here. Without you, there would be no money for development, no aircraft to compete with (Taurus G4), and no money to stay in the US. Thank you to everyone from the workers in production, plastics, warehouse, logistics, quality control, support, administration, development [...]." (Boscarol, 2011, p.61)

An inclusive leadership style is based on respect for all stakeholders, so such a leader strives to listen to each employee and understand their needs as best as possible, as the Ivo Boscarol, CEO of Pipistrel pointed out in the interview (Bizovičar, 2017):

"We have always shared all cash prizes and profits with all employees, because everyone in the company deserves success [...]. Today, of course, it is important that the basic salary allows a normal standard of living. But also for young people it is more and more important what they do in life, that they can invest their energy in a visible result. That they can be satisfied with it, that they can proudly say where they work, that the working day is arranged in such a way that there is enough time for family and other activities, that they are respected by colleagues and management and that they have the weekends to themselves."

It can be argued that an inclusive leader combines two important components, intellectual ability and emotion. These help him to maintain a high level of work commitment and benefit in terms of a high level of innovation. Moreover, this spontaneously enables him or her to have a far-reaching reach that is linked to the company's vision and strategy. Within this, they also gained the NASA Green Flight Challenge, which attracted the attention of potential investors who can see a technically sophisticated product worth investing in (Željan and Voh Boštic, 2011). 
If positive personal values are a prerequisite for building and creating an inclusive environment and relationship between the leader and the employees, then the main syntagm of their further development and progress is genuine twoway communication:

"The last time I gave a lecture in a school, and when I had finished the lecture there was silence. Then I added that if I finished that lecture anywhere in America, everyone would be waiting for my last word, and when I said it, they would raise their hands and ask questions. I emphasized that I think this is true for them as well. Everyone would like to ask something, but because they were educated like that in school, no one dares to raise their hand and ask, and this is the burial of Slovenian innovation, thinking and so on. Everyone who dreams of going outside is not cut out for it if you are so shy and afraid. Outside you have to expose yourself to be better than everyone else. When everyone is running outside, you have to jump. The fact is, people here are afraid to ask at the end of the lecture because they're afraid of how eighty people will look at them if they raise their hand. That's our problem." (Vladić, 2017, p.69)

An inclusive leader is always available to their employees because they know that communication is key to maintaining engagement and motivation to move forward. Questions play an extremely important role in this process because they stimulate curiosity and thus have a positive impact on innovation. Questions are a way to understand the perceptions of different team members. In this way, all communication participants have the opportunity to broaden their horizons, test their existing beliefs and replace previous thinking patterns with new, more meaningful and effective ones. The result of the reciprocal process is the growth of human capital, which is expressed in the development of individual potential. For their realization and affirmation, the self-confidence and courage of an inclusive leader is needed, whose energy inspires employees to believe in their innovative abilities, which leads to the realization of the planned goals:

"When I said then that we must build an airplane that would fly two hundred miles an hour with fifty horses, fly a hundred yards, and weigh two hundred and fifty pounds, they said it could not be done. But a few weeks later, when it came to what systems we should put in, how different, innovative, think differently than all the other manufacturers, we did it. And still today, the philosophy is that our aircraft use significantly less energy than others. That makes them better, more efficient, quieter. That's why they have a competitive advantage over everyone else." (CEO, Pipistrel)

Work engagement and the inclusive environment created thus become the fundamental basis of the inexhaustible innovative capability of employees and the company as a whole, which cannot be disrupted by any negative events from the environment:

"We are strong because every day brings a new crisis. In the morning we often don't know what it will be like at noon. One time a plane crashes over Ukraine, the second time it crashes in Argentina, the third time there are floods in 
Australia, the fourth time there is an embargo in Iran. In fact, the more failures you have, the more you learn and the stronger you go into the future. We have made many mistakes and we are still making them, so it will probably be in the future. Mistakes are the best investment because they allow you to be strong in times of crisis, to be a strong team. Mistakes are something positive, they can have a very positive effect in the long run [...]. To withstand such shocks, there are rules: (1) as many different markets as possible, even remote ones, and of course they are not easy; (2) as many different models as possible, so that if one doesn't sell, you have another, a third, and so on, and you are less vulnerable; (3) organize so that if tomorrow demand drops, you don't have to lay people off, i.e. you should hand over as much production as possible to your business partners in order to strengthen your employees. By making mistakes, one learns to organize oneself in such a way that one can act to one's advantage even in the face of strong upheavals." (CEO, Pipistrel)

On the contrary, from this moment on all crises and business earthquakes become a source of learning and inspiration for the introduction of such changes as will make possible further unshakable business and progress in the planned direction. Despite all the business turbulence and tempting financial benefits from different business models, an inclusive leader insists on adherence to values:

"From the successful giants I have met, I have learned that humility is the greatest secret to success [...]. The key to success is to work for the long term and respect values. Today, it's not hard to succeed at the expense of others. If you succeed at the expense of your employees, at the expense of your suppliers, at the expense of your customers, it's easy. It just won't last. If you take advantage of eight-year-old girls working semi-free for you somewhere in third world countries, you can be successful. However, being successful and sticking to values is not so easy these days." (CEO, Pipistrel)

Along with empathy, therefore, honesty and fair dealings with one another are essential elements of inclusive leadership that fills employees with confidence and security. Thus freed from prejudice or fear, employees identify with the company's vision, are more committed, innovative and thus more productive in their work. The result is a global success expressed in the construction of the Pipistrel plant in the Chinese city of Jurong, which will include the production of two aircraft, the Alpha Electro and the four-seater Panthera, as well as the development of a 19-seater ship (Dumančič, 2018).

In the situation in the business world where almost all companies specialise in a particular segment of the business field, there is much scope for their mutual cooperation. In fact, their cooperation is essential if they are to survive economic turmoil and make visible progress in their own field. In such circumstances, companies no longer rely solely on their own innovative capabilities, but enter into business partnerships to acquire those innovative capabilities that they do not possess or whose implementation is judged to be economically unjustified. This 
is how Pipistrel entered into a partnership and built a business ecosystem, according to its founder Ivo Boscarol:

"The Taurus G4 aircraft will be used for further research, development and improvements as part of the Mahepa project (modular approach to hybrid electric propulsion architecture), involving partners from Germany H2FLY GmbH Compact Dynamics, DLR - German Aerospace Center and Ulm University, and Delft University of Technology from the Netherlands, Politecnico di Milano and the University of Maribor [...]. The summers that have taken place over the last few weeks in private at Maribor Airport have proven that even in these extremely challenging times, with international collaboration, despite all the constraints and challenges that Covid brings, it is possible to achieve world-class development performance."(Boscarol, 2020)

The result of this collaboration is the maiden flight of a four-seat hydrogenpowered hybrid electric aircraft, which will form the basis for another project of a 19-seat hydrogen fuel cell-powered passenger aircraft capable of flying up to 1,000 kilometres in two hours, silently and with zero emissions.

\section{CRITICAL ANALYSIS AND DISCUSSION}

From the exploratory study conducted, a number of findings are obtained with the aim of enhancing the understanding of the role of the emerging discipline of inclusive leadership (Najmaei and Sadeghinejad, 2019) in improving innovation capability. This research contributes to and enriches the existing body of research on leadership and innovation (Alblooshi, Shamsuzzaman and Haridy, 2020). Moreover, this work thus contributes to the call for more empirical and conceptual studies on inclusive leadership and its link to innovativeness. This section continues with the critical analysis that addresses the response to RQ1 and RQ2.

\subsection{How Could Managers Increase the Innovative Skills of Employees and Organization by Encouraging Employee Engagement?}

Whether it is at the level of an individual supervisor, a work group, or the highest level of leadership within the organization, effective leadership for innovation is paramount. Therefore, we treat this topic area as particularly important, but so far rather neglected in empirical studies (Anderson, Potočnik and Zhou, 2014). An inclusive leader is characterized primarily by a strong commitment, the cornerstone of which is personal values. He therefore strives to combine personal values with an inclusive leadership style, with employees at the center of his concern (Bourke, 2016).

The owner and founder of Pipistrel, Ivo Boscarol, emphasizes at the very beginning of the interview the importance of values, which for him are the most important guide for every decision and activity in everyday life and in business. 
He highlights the three most important values on which the whole strategy and vision of the company is based, as well as the organizational climate and innovation as their complementary part. Trust, courage and humility form the basis for healthy interaction and business. He adds two others whose purpose is to establish a genuine and direct contact with employees. It is empathy and gratitude that enable all messages to reach employees in a form that is most understandable to them.

As Kotter and Cohen (2002) explain, people are less likely to change because a good explanation or rational analysis is supposed to influence their thinking. For all of them, it is mainly the associated emotions that the leader influences when telling them the truth. In this way, employees recognize the authenticity of the leader, so they can easily build a trusting relationship with him, and thus they have the necessary energy to design creative solutions, work hard and achieve top results. The basic motive of employees is to be pleased and grateful that a person who knows how to recognize and nurture their potential is leading them. An important part of trust comes from the fact that a leader's words are always followed by actions when it comes to fulfilling his forecasts, rewarding employees and sharing profits.

In an inclusive environment, employees are empowered and encouraged to contribute to decisions and participate in discussions, speak openly, and promote and implement new ideas (Jong and Hartog, 2010). Pipistrel employees have a free hand in their work and there is no system of shaping or framing by the strategic management of the employees. On the contrary, considering the common denominator in terms of strategy and vision, employees can think within their own desires and associated potentials. An inclusive environment where everyone can express their thoughts certainly opens up opportunities for friction and criticism. The same is true for Pipistrel, where diversity of opinion contributes to more effective collaboration, while criticism promotes learning and consistent development for all involved (Bourke, 2016). Apart from this, leadership plays a crucial role for their organizations in managing, assessing and addressing complex risks (Pacaiova and Nagyova, 2015; 2019), where our case study company also excels.

From all this, we can conclude that leaders could promote employee work engagement to enhance employee and organizational innovativeness mainly by implementing values such as: Trust, Courage, Humility, Empathy and Gratitude. In this way, leaders could establish or improve the existing strategy and organizational climate. In this, the focus is on people who have the opportunity to express their thinking and potentials without restrictions, which directly leads to work commitment, motivation and innovation. 


\subsection{What Factors Have a Significant Impact on Work Engagement and Innovation Capability?}

Building an inclusive environment means, first and foremost, setting a strategy and a vision and allowing each employee to express his or her own opinion. The points mentioned above and explained in detail in the previous chapter are the basis on which employees will participate inside and outside the company. The most important thing for the successful operation of an inclusive environment is undoubtedly the daily communication with the employees.

Inclusive presenters consider the opinions of their audience - not just who they are, but what they have to say. Whether they are leading small teams or an entire company, it is essential to provide regular opportunities for employees to voice their needs and concerns. It's the inclusive leader's job to ask them for feedback, acknowledge their input, and implement all that they objectively can. In addition, leaders often say they want to listen to employees, but don't actually offer opportunities for feedback or questions. Yet this is the quickest way for employees to become alienated from both the work and the vision of the company. To avoid this, it is advisable to be genuine and credible in communication (Zandan and Shalett, 2020).

Ivo Boscarol is simple, genuine, and empathetic in communication. We speak of a man who does not have one face for public, another for private, and a third for business. He is always the same in his appearances, with a distinct optimism and consistency that gives people a sense of calm and confidence. According to Ivo Boscarol, communication with employees is crucial, and the ability to ask questions is central because it neutralizes fear, which is destructive to an employee's creativity and skills. When you ask a question, you have to stand out, and this is a must for an individual or team that wants to be among the top or the best in the world. Asking questions stimulates curiosity, builds an individual's personality, strengthens interpersonal relationships and gathers new knowledge.

It should be noted that knowledge, which in a sense represents problem-oriented solutions, includes everything that certain actors use to promote actions, relationships, solutions, etc., regardless of the rationality or purpose of the knowledge element, both expertise and theory, practical rules and techniques, as well as recipes, mnemonics, worldviews, habits, superstitions, and religious or mystical beliefs of all kinds (Kovač, Mühlbacher and Kodydek, 2012). Knowledge is what positively influences the ability to innovate and enables the development of an organization. In fact, focusing on the development of human capital is an important prerequisite for the success and competitive advantage of a firm (AlQershi et al., 2020).

In Pipistrel, times of crisis are therefore seen as an opportunity to increase one's own development potential by learning from mistakes. In the long run, there are positive effects, such as a greater number of different markets, several different aircraft models, redistribution of work among partners, etc. At the same time, the crisis is also an opportunity to take a step forward and overtake the competition. 
Moreover, innovation has become a critical factor in achieving long-term competitive advantage and sustainable development goals (Maletič, Gomišček and Maletič, 2021).

We can conclude that work engagement and innovativeness are significantly influenced above all by authentic communication, which must be honest and genuine in content. This creates an organizational climate in which there is a constant exchange of mutual opinions and dissemination of knowledge, which does not run away from any crisis but seeks inspiration and development opportunities in it.

\section{CONCLUSION}

In the research, we found that leaders can foster employee work engagement to increase employee and organizational innovativeness primarily by implementing personal values such as trust, courage, humility, empathy, and gratitude. At the same time, they need to create an organizational climate that allows and encourages dissent, discussion and criticism, thus contributing to personal development, learning and innovation of individuals.

The sustaining element of a good organizational climate and high motivation is authentic communication, characterized by the genuineness and good intentions of the leader focused on employee development. An important generator of engagement and innovation is the crisis in which the previous way of organizing and working contributes to more learning and knowledge accumulation, and thus to achieving a competitive advantage.

Moreover, we find that business ecosystems play an important role in innovation, to which experts attribute a promising future (Lyman, Ref and Wright, 2018). Their purpose is to overcome obstacles, network, form partnerships, and increase their own excellence, which translates into the development of potential and increased sales of products.

All this is a good guide for many companies trying to find appropriate and effective ways to innovate successfully, but still imitate and strive to become innovators (Le and Lei, 2019). Indeed, just over half of managers believe that their companies are unable to innovate effectively, which consequently brings the aforementioned skills gap to the fore (PwC, 2019). Add to this the implications associated with the "covid situation" and new digital technologies, and it is clear that innovation is and will remain the most important issue in the business world and also in the part of the scientific world that deals with organizations. This is also supported by a report from the European Commission, Directorate for Development and Innovation (De Nul, Breque and Petridis, 2021), which highlights the importance of Industry 5.0 and suggests close involvement of employees in the design and implementation of new industrial technologies, including robotics and artificial intelligence. 
Research findings can help organizations engage employees to increase organizational innovation and employees as individuals. Moreover, this study aims to better understand the relationship between inclusive leadership and innovativeness by highlighting the special role of fostering work engagement. In this way, organizations can develop more appropriate employee leadership strategies to achieve engagement and high innovativeness at both the employee and organizational levels.

The research deepened the understanding of the importance of exploring such specific topics that had not been explored in the past. At the same time, the research contributed to a greater updating and enrichment of the literature in the field of leadership, work engagement and innovativeness.

\subsection{Research Limitations and Suggestions for Further Research}

The research provided concrete results and gave important directions for research in the field of leadership and related work engagement and innovativeness. We did not include employee surveys in the research that would further illuminate their attitudes toward work engagement and innovativeness.

For further research, we propose a more in-depth case study that additionally includes an examination of organizational structure and key work processes that support innovation. In addition, we propose to examine three or four examples of comparable highly innovative organizations to achieve greater generalization of the findings.

\section{ACKNOWLEDGEMENTS}

This research was supported by the Slovenian Research Agency; Program No. P5-0018-Decision Support Systems in Digital Business.

\section{REFERENCES}

Adler, P.S. and Shenhar, A.J., 1990. Adapting Your Technological Base: The Organizational Challenge. Sloan Management Review, 32(1), pp.25-37.

Agarwal, R. and Selen, W., 2009. Dynamic Capability Building in Service Value Networks for Achieving Service Innovation. Decision Sciences, [e-journal] 40(3), pp.431-475. DOI: 10.1111/j.1540-5915.2009.00236.x.

Akman, G. and Yilmaz, C., 2008. Innovative capability, innovation strategy and market orientation: an empirical analysis in turkish software industry. International Journal of Innovation Management, [e-journal] 12(01), pp.69-111. DOI: 10.1142/S1363919608001923. 
Alblooshi, M., Shamsuzzaman, M. and Haridy, S., 2020. The relationship between leadership styles and organisational innovation: A systematic literature review and narrative synthesis. European Journal of Innovation Management, [e-journal] 24(2), pp.338-370. DOI: 10.1108/EJIM-11-2019-0339.

AlQershi, N.A., Diah, M.L.B.M., Latiffi, A.B.A. AND Ahmad, W.N.K.W., 2020. Strategic Innovation and Competitive Advantage of Manufacturing SMEs: The Mediating Role of Human Capital. Quality Innovation Prosperity, [e-journal] 24(3), pp.70-89. DOI: 10.12776/qip.v24i3.1493.

Anderson, N., Potočnik, K. and Zhou, J., 2014. Innovation and Creativity in Organizations: A State-of-the-Science Review, Prospective Commentary, and Guiding Framework. Journal of Management, [e-journal] 40(5), pp.1297-1333. DOI: $10.1177 / 0149206314527128$.

Aragón-Correa, J.A., García-Morales, V.J. and Cordón-Pozo, E., 2007. Leadership and organizational learning's role on innovation and performance: Lessons from Spain. Industrial Marketing Management, [e-journal] 36(3), pp.349-359. DOI: 10.1016/j.indmarman.2005.09.006.

Avery, D.R., McKay, P.F., Wilson, D.C. and Volpone, S., 2008. Attenuating the effect of seniority on intent to remain: The role of perceived inclusiveness. In: Academy of Management, Meeting of the Academy of Management: 2008 Annual Meeting. Anaheim, California, 8-13 August 2008.

Barratt, M., Choi, T.Y. and Li, M., 2011. Qualitative case studies in operations management: Trends, research outcomes, and future research implications. Journal of Operations Management, [e-journal] 29(4), pp.329-342. DOI: 10.1016/j.jom.2010.06.002.

Bizovičar, M., 2017. Anketa: Zakaj menite, da ste zaželen delodajalec?. DELO, [online] 28 Sept. Available at: <https://old.delo.si/gospodarstvo/kariera/anketazakaj-menite-da-ste-zazelen-delodajalec.html> [Accessed 16 July 2021].

Björkdahl, J. and Börjesson, S., 2012. Assessing firm capabilities for innovation. International Journal of Knowledge Management Studies, [e-journal] 5(1/2), p.171. DOI: 10.1504/IJKMS.2012.051970.

Boscarol, I., 2011. NASA Blog. Ajdovščina: Pipistrel.

Boscarol, I., 2020. Pipistrelovo 19-sedežno letalo bo poletelo pred letom 2030. Interviewed by Borut Podgoršek. [portal] Sierra5.net, 14 Dec. Available at: $<$ https://www.sierra5.net/novice-novo/novice/item/3737-pipistrelovo-19sedezno-letalo-bo-poletelo-pred-letom-2030> [Accessed 16 July 2021].

Bourke, J., 2016. The six signature traits of inclusive leadership. Deloitte Insights, [online] 14 April. Available at: <https://www2.deloitte.com/us/en/insights/topics/talent/six-signature-traits-ofinclusive-leadership.html> [Accessed 16 July 2021]. 
Caulfield, J.L. and Senger, A., 2017. Perception is reality: change leadership and work engagement. Leadership \& Organization Development Journal, [e-journal] 38(7), pp.927-945. DOI: 10.1108/LODJ-07-2016-0166.

Choi, S.B., Tran, T.B.H. and Kang, S.-W., 2017. Inclusive Leadership and Employee Well-Being: The Mediating Role of Person-Job Fit. Journal of Happiness Studies, [e-journal] 18(6), pp.1877-1901. DOI: 10.1007/s10902-016-9801-6.

De Nul, L., Breque, M. and Petridis, A., 2021. Industry 5.0: towards a sustainable, human centric and resilient European industry. LU: Publications Office of the European Union.

De Spiegelaere, S., Van Gyes, G., De Witte, H. and Van Hootegem, G., 2015. Job Design, Work Engagement and Innovative Work Behavior: A Multi-Level Study on Karasek's Learning Hypothesis. Management Revue, [e-journal] 26(2), pp.123-137. DOI: $10.1688 / \mathrm{mrev}-2015-02-D e S p i e g e l a e r e$.

Denning, S., 2013. Why Agile can be a game changer for managing continuous innovation in many industries. Strategy \& Leadership, [e-journal] 41(2), pp.5-11. DOI: $10.1108 / 10878571311318187$.

Doyle-Kent, M. and Kopacek, P., 2020. Industry 5.0: Is the Manufacturing Industry on the Cusp of a New Revolution?. In: N.M. Durakbasa and M.G. Gençyılmaz, eds., Proceedings of the International Symposium for Production Research 2019. Vienna, Austria, 28-30 August 2019. Cham: Springer International Publishing. pp.432-441. DOI: 10.1007/978-3-030-31343-2_38.

Dumančič, M., 2018. Pipistrel zasadil lopato na Kitajskem. RTVSLO.si, [online] 11 April. Available at: <https://www.rtvslo.si/gospodarstvo/pipistrel-zasadillopato-na-kitajskem/451649> [Accessed 16 July 2021].

Eagly, A.H., Johannesen-Schmidt, M.C. and Van Engen, M.L., 2003. Transformational, transactional, and laissez-faire leadership styles: A metaanalysis comparing women and men. Psychological Bulletin, [e-journal] 129(4), pp.569-591. DOI: 10.1037/0033-2909.129.4.569.

Eisenhardt, K.M., 1989. Building Theories from Case Study Research. The Academy of Management Review, [e-journal] 14(4), pp.532-550. DOI: $10.2307 / 258557$.

Iddris, F., 2016. Innovation Capability: A Systematic Review and Research Agenda. Interdisciplinary Journal of Information, Knowledge, and Management, [e-journal] 11, pp.235-260. DOI: https://doi.org/10.28945/3571.

Jong, J.D. and Hartog, D.D., 2010. Measuring Innovative Work Behaviour. Creativity and Innovation Management, [e-journal] 19(1), pp.23-36. DOI: 10.1111/j.1467-8691.2010.00547.x. 
Kahn, W.A., 1990. Psychological Conditions of Personal Engagement and Disengagement at Work. Academy of Management Journal, [e-journal] 33(4), pp.692-724. DOI: $10.5465 / 256287$.

Kotter, J.P. and Cohen, D.S., 2002. The Heart of Change: Real-Life Stories of How People Change Their Organizations. Boston, Massachutsetts: Harvard Business Review Press. Available at: <https://store.hbr.org/product/the-heart-ofchange-real-life-stories-of-how-people-change-their-organizations/2549> [Accessed 16 July 2021].

Kovač, J., Mühlbacher, J. and Kodydek, G., 2012. Uvod v management sprememb. Kranj: Moderna organizacija v okviru Fakultete za organizacijske vede.

Lawson, B. and Samson, D., 2001. Developing Innovation Capability in Organisations: A Dynamic Capabilities Approach. International Journal of Innovation Management (ijim), 05(03), pp.377-400.

Le, P.B. and Lei, H., 2019. Determinants of innovation capability: the roles of transformational leadership, knowledge sharing and perceived organizational support. Journal of Knowledge Management, [e-journal] 23(3), pp.527-547. DOI: 10.1108/JKM-09-2018-0568.

Liao, S.-H., Chen Ch.-Ch., Hu, D.-Ch., Chung, Y.-Ch. And Liu, Ch.-L., 2017. Assessing the influence of leadership style, organizational learning and organizational innovation. Leadership \& Organization Development Journal, [e-journal] 38(5), pp.590-609. DOI: 10.1108/LODJ-11-2015-0261.

Lyman, M., Ref, R. and Wright, O., 2018. Cornerstone of future growth: Ecosystems. Research Report. Accenture. Available at: <https://www.accenture.com/_acnmedia/PDF-77/Accenture-StrategyEcosystems-Exec-Summary-May2018-POV.pdf\#zoom=50>.

Maletič, M., Gomišček, B. and Maletič, D., 2021. The missing link: sustainability innovation practices, non-financial performance outcomes and economic performance. Management Research Review. (ahead-of-print). DOI: 10.1108/MRR-09-2020-0562.

McMillan, C., 2010. Five competitive forces of effective leadership and innovation. Journal of Business Strategy, [e-journal] 31(1), pp.11-22. DOI: 10.1108/02756661011012741.

Moore, J.F., 1993. Predators and Prey: A New Ecology of Competition. Harvard Business Review, [online] 1 May. Available at: <https://hbr.org/1993/05/predators-and-prey-a-new-ecology-of-competition> [Accessed 17 July 2021]. 
Morgan, J., 2017. Why the Millions We Spend on Employee Engagement Buy Us So Little. Harvard Business Review, [online] 10 March. Available at: $<\mathrm{https} / / / \mathrm{hbr}$.org/2017/03/why-the-millions-we-spend-on-employee-engagementbuy-us-so-little> [Accessed 16 July 2021].

Najmaei, A. and Sadeghinejad, Z., 2019. Inclusive Leadership: A Scientometric Assessment of an Emerging Field. Diversity within Diversity Management, [e-journal] 22, pp.221-245. DOI: 10.1108/S1877-636120190000022012.

Nembhard, I.M. and Edmondson, A.C., 2006. Making it safe: the effects of leader inclusiveness and professional status on psychological safety and improvement efforts in health care teams. Journal of Organizational Behavior, [e-journal] 27(7), pp.941-966. DOI: 10.1002/job.413.

Pacaiova, H. and Nagyova, A., 2015. Risk assessment Methodology in SMES. In: SGEM (International Multidisciplinary Scientific GeoConferences), 15th International Multidisciplinary Scientific GeoConference SGEM 2015: Conference Proceedings. Albena, Bulgaria, 18-24 June 2015. Curran Associates. pp.769-782. DOI: 10.5593/SGEM2015/B52/S23.102.

Pacaiova, H. and Nagyova, A., 2019. Risk Based Thinking - New Approach for Modern Enterprises' Management. In J.I. Kantola, S. Nazir and T. Barath, eds. Advances in Human Factors, Business Management and Society. Cham: Springer International Publishing. pp.524-536. DOI: 10.1007/978-3-319-94709-9_52.

Prasad, B. and Junni, P., 2016. CEO transformational and transactional leadership and organizational innovation: The moderating role of environmental dynamism. Management Decision, [e-journal] 54(7), pp.1542-1568. DOI: 10.1108/MD-11-2014-0651.

PricewaterhouseCoopers (PwC), 2019. PwC's 22nd Annual Global CEO Survey: CEOs' curbed confidence spells caution. [pdf] PwC. Available at: 〈https://www.pwc.com/mu/pwc-22nd-annual-global-ceo-survey-mu.pdf> [Accessed: 16 July 2021].

Rich, B.L., LePine, J.A. and Crawford, E.R., 2010. Job engagement: Antecedents and effects on job performance. Academy of Management Journal, [e-journal] 53(3), pp.617-635. DOI: 10.5465/AMJ.2010.51468988.

Schaufeli, W.B., 2018. Work engagement in Europe: Relations with national economy, governance and culture. Organizational Dynamics, [e-journal] 47(2), pp.99-106. DOI: 10.1016/j.orgdyn.2018.01.003.

Schaufeli, W.B., Salanova, M., González-Romá, V. and Bakker, A.B., 2002. The Measurement of Engagement and Burnout: A Two Sample Confirmatory Factor Analytic Approach. Journal of Happiness Studies, [e-journal] 3(1), pp.71-92. DOI: $10.1023 / \mathrm{A}: 1015630930326$. 
Som, O., Kirner, E. and Jäger, A., 2015. The Absorptive Capacity of Non-R\&DIntensive Firms. In: O. Som and E. Kirner, eds. 2015. Low-Tech Innovation. Springer: Springer Books. pp.145-164. Available at: <https://econpapers.repec.org/bookchap/sprsprchp/978-3-319-09973-6_5f9.htm> [Accessed 17 July 2021].

Szczepańska-Woszczyna, K., 2015. Leadership and Organizational Culture as the Normative Influence of Top Management on Employee's Behaviour in the Innovation Process. Procedia Economics and Finance, [e-journal] 34, pp.396-402. DOI: 10.1016/S2212-5671(15)01646-9.

Talmar, M., Walrave, B., Podoynitsyna, K.S., Holmström and Rommea, A.G.L., 2020. Mapping, analyzing and designing innovation ecosystems: The Ecosystem Pie Model. Long Range Planning, [e-journal] 53(4), p. 101850. DOI: 10.1016/j.lrp.2018.09.002.

Terziovski, M., 2007. Building Innovation Capability in Organizations: An International Cross-Case Perspective. World Scientific Books, No. p.492. Available at: <https://ideas.repec.org/b/wsi/wsbook/p492.html> [Accessed 16 July 2021].

Turisova, R., Sinay, J., Pacaiova, H., Kotianova,Z. and Glatz, J., 2020. Application of the EFQM Model to Assess the Readiness and Sustainability of the Implementation of I4.0 in Slovakian Companies. Sustainability, [e-journal] 12(14), p.5591. DOI: 10.3390/su12145591.

Villaluz, V.C. and Hechanova, M.R.M., 2018. Ownership and leadership in building an innovation culture. Leadership \& Organization Development Journal, [e-journal] 40(2), pp.138-150. DOI: 10.1108/LODJ-05-2018-0184.

Vladić, N., 2017. Od talenta do uspeha. Kranj: Izdano v samozaložbi.

Yin, R.K., 2018. Case study research and applications: Design and Methods. Sixth edition. SAGE Publications Inc.

Zandan, N. and Shalett, L., 2020. What Inclusive Leaders Sound Like. Harvard Business Review, [online] 19 Nov. Available at: <https://hbr.org/2020/11/whatinclusive-leaders-sounds-like> [Accessed 16 July 2021].

Željan, K. and Voh Boštic, A., 2011. Pipistrel osvojil Nasino nagrado. DELO, [online] 3 Oct. Available at: <https://old.delo.si/gospodarstvo/podjetja/pipistrelosvojil-nasino-nagrado-2.html> [Accessed 16 July 2021].

Zhexembayeva, N., 2020. Stop Calling It "Innovation". Harvard Business Review, [online] 19 Feb. Available at: <https://hbr.org/2020/02/stop-calling-itinnovation> [Accessed 16 July 2021]. 


\section{ABOUT AUTHORS}

Nenad Vladić ${ }^{0000-0002-6443-4452}$ (N.V.) - University of Maribor, Faculty of Organizational Sciences, Slovenia, PhD Student, e-mail: nenad.vladic@student.um.si.

Damjan Maletič $\check{c 000}^{0002-6871-2720}$ (D.M.) - University of Maribor, Faculty of Organizational Sciences, Slovenia, Assist. Prof., e-mail: damjan.maletic@um.si.

Matjaž Maletič $\check{c}^{000-0002-3845-744 X}$ (M.M.) - University of Maribor, Faculty of Organizational Sciences, Slovenia, Assist. Prof., e-mail: matjaz.maletic@um.si.

\section{AUTHOR CONTRIBUTIONS}

Conceptualization, N.V. and M.M.; Methodology, N.V. and M.M.; Validation, M.M. and D.M.; Formal analysis, N.V.; Investigation, N.V.; Resources, N.V.; Data curation, N.V.; Original draft preparation, N.V. and M.M.; Review and editing, M.M. and D.M.; Supervision, M.M. and D.M.

\section{CONFLICTS OF INTEREST}

The authors declare no conflict of interest. The funders had no role in the design of the study; in the collection, analyses, or interpretation of data; in the writing of the manuscript, or in the decision to publish the results.

(C) 2021 by the authors. Submitted for possible open access publication under the terms and conditions of the Creative Commons Attribution (CC-BY) license (http://creativecommons.org/licenses/by/4.0/). 